Abstracta Iranica Abstracta Iranica

Revue bibliographique pour le domaine irano-aryen

Volume 31 | 2011

Comptes rendus des publications de 2008

\title{
Iqbal. London/Oxford, I.B. Tauris/Oxford Centre for Islamic Studies, 2006, 157 p. (Makers of Islamic Civilization)
}

Ève Feuillebois-Piérunek

\section{(2) OpenEdition}

1 Journals

Édition électronique

URL : http://journals.openedition.org/abstractairanica/39809

DOI : 10.4000/abstractairanica.39809

ISSN : 1961-960X

Éditeur :

CNRS (UMR 7528 Mondes iraniens et indiens), Éditions de l'IFRI

\section{Édition imprimée}

Date de publication : 15 mai 2011

ISSN : 0240-8910

Référence électronique

Ėve Feuillebois-Piérunek, « Iqbal. London/Oxford, I.B. Tauris/Oxford Centre for Islamic Studies, 2006, 157 p. (Makers of Islamic Civilization)», Abstracta Iranica [En ligne], Volume 31 | 2011, document 293, mis en ligne le 11 octobre 2012, consulté le 03 octobre 2020. URL : http://journals.openedition.org/ abstractairanica/39809; DOI : https://doi.org/10.4000/abstractairanica.39809

Ce document a été généré automatiquement le 3 octobre 2020.

Tous droits réservés 


\title{
Iqbal. London/Oxford, I.B. Tauris/ Oxford Centre for Islamic Studies, 2006, 157 p. (Makers of Islamic Civilization)
}

\author{
Ève Feuillebois-Piérunek
}

1 Destiné au grand public anglo-saxon, l'ouvrage présente le philosophe et poète Muhammad Iqbāl (1877-1938) en se concentrant sur sa pensée telle qu'elle apparaît dans ses propres écrits.

2 Le premier chapitre présente la vie, la personnalité et l'œuvre d'Iqbāl en s'appuyant sur la biographie écrite par le fils du poète et en insistant sur les différentes phases de son mûrissement intellectuel. Le deuxième chapitre analyse les principaux thèmes de la poésie d'Iqbal (nature, vie comme quête, intellect et amour, Islam, Orient et Occident), tandis que le $3^{\mathrm{e}}$ chapitre est consacré aux caractéristiques de son art poétique. Le $4^{\mathrm{e}}$ chapitre traite des deux principaux ouvrages philosophiques d'Iqbal, Le Développement de la pensée métaphysique en Perse et La Reconstruction de la pensée religieuse en Islam. Le $5^{\mathrm{e}}$ chapitre s'intéresse à la pensée sociale et politique de cet auteur aussi sincèrement musulman qu'ouvert à la modernité. Le $6^{e}$ chapitre enfin rassemble des observations sur la postérité de son œuvre. Une excellente introduction à cet auteur aussi complexe qu'attachant.

\section{INDEX}

Thèmes: 11.1.2. Littérature persane moderne 
AUTEURS

ÈVE FEUILLEBOIS-PIÉRUNEK

Université Sorbonne Nouvelle - Paris 3 - Mondes iranien et indien 